\title{
The Presence of Cucumber Mosaic Virus in Pot Marigold (Calendula officinalis L.) in Serbia
}

\author{
Dragana Milošević · Maja Ignjatov • Zorica Nikolić · Jelica Gvozdanović Varga • \\ Gordana Tamindžić · Ivana Stanković · Branka Krstić
}

\begin{abstract}
Summary: During 2014 a total of 67 pot marigold samples from five different localities in the Province in Vojvodina were collected and analysed for the presence of Cucumber mosaic virus (CMV) and Impatiens necrotic spot virus (INSV) using commercial double-antibody sandwich (DAS)-ELISA kits. CMV was detected serologically in all inspected localities in $67.16 \%$ collected samples. None of the analysed samples was positive for INSV. The virus was successfully mechanically transmitted to test plants including Chenopodium amaranticolor, C. quinoa, Datura stramonium, Nicotiana tabacum 'Samsun' and N. glutinosa, as well as pot marigold seedlings, confirming the infectious nature of the disease. The presence of CMV in pot marigold plants was further verified by RT-PCR and sequencing, using the specific primers CMV CPfwd/CMVCPrev that amplify coat protein (CP) gene. Phylogenetic analysis based on the CP gene sequences showed clustering of the selected isolates into three subgroups, IA, IB and II, and Serbian CMV isolates from pot marigold belong to subgroup II.

Keywords: Calendula, coat protein gene, cucumber mosaic virus, Impatiens necrotic spot virus, isolates, marigold, RT-PCR, sequencing
\end{abstract}

\section{Introduction}

Serbia is situated in the region suitable for the cultivation of medicinal plants owing to the favourable climate, soil and unpolluted environment. According to unofficial estimates, approximately 3,500 ha of medicinal plants are grown and the most significant production area is in the Province of Vojvodina, Serbia.

Calendula officinalis L. (family Asteraceae), commonly known as pot marigold, is a flowering perennial ornamental, rich in essential oils, that is commonly grown in gardens or as potted plant all over Europe. The flower is normally used as food additive to confer both colour and flavour to foods (Blumenthal 2000, Hamburger et al. 2003). Marigold is also widely used in traditional and homeopathic medicine as infusions and ointments prepared with its petals. It exhibits several therapeutic activities, such as antiinflammatory, anti-tumorogenic and cytotoxic activities (Kalvatchev et al. 1997, Ramos et al. 1998, Blumenthal 2000, Hamburger et al. 2003).

D. Milošević* · M. Ignjatov · Z. Nikolić · J. Gvozdanović Varga · G. Tamindžić

Institute of Field and Vegetable Crops, 30 Maksima Gorkog, 21000 Novi Sad, Serbia

e-mail: dragana.milosevic@nsseme.com

I. Stanković · B. Krstić

University of Belgrade, Faculty of Agriculture, Institute of Plant Protection, Department of Phytopathology, Nemanjina 6, 11000 Belgrade, Serbia
Some of the marigold plants developed viraldisease-like symptoms consisting of yellowing, mosaic, vein chlorosis and mild curling. The infected plants were stunted, yielding a small number of twisted and deformed flowers. Growth reduction was exhibited by the production of small leaves clustering around the main stem. The severely infected plants tended to cease growth showing necrosis at the top. According to previous data, the two major viruses of marigold are Cucumber mosaic virus (CMV) and Impatiens necrotic spot virus (INSV) (Hanson et al. 1951, Ghotbi 2013).

The most common viral disease of pot marigold is described as "chlorotic mottle" and it is caused by CMV. As a type species of Cucumorirus genus, it is reported to infect 1287 plant species in 518 genera belonging to 100 families (Edwardson \& Christie 1997). It was described for the first time in America in 1916, as a cucumber and squash disease agent (Francki et al. 1979). Since then, CMV has become a widespread virus, though it is predominantly found in temperate regions with the most favourable conditions for the growth of its vectors - aphids. CMV is transmitted in a non-persistent manner by more than 80 aphid species, and the most efficient CMV vectors are Myrus persicae and Aphis gossypii (Garcia-Arenal \& Palukaitis 2008).

Acknowledgements: This research was supported by the grant TR31030 and III 43001 of the Ministry of Education, Science, and Technological Development of the Republic of Serbia and EU Commission project AREA, No 316004. 
Considering the frequent presence of CMV on various plant species in Serbia (Petrović et al. 2010, Stanković et al. 2011, Vučurović et al. 2011, Vučurović et al. 2012, Milojević et al. 2013), after the first detection of CMV infecting pot marigold (Milošević et al. 2015), a survey was conducted in the main pot marigold producing areas in the Province of Vojvodina in order to detect the presence and distribution of CMV and to determine the genetic relationship of Serbian pot marigold CMV isolates with those from other parts of the world.

\section{Materials and Methods}

\section{Survey and sample collection}

During 2014, a total of 67 samples of symptomatic pot marigold plants were randomly collected from five crops at five different localities of South Bačka (Srbobran, Đurđevo), Srem (Ruma) and Central Banat districts (Zrenjanin, Žitište) in the Province of Vojvodina. Samples of pot marigold plants comprised of leaves which exhibited typical symptoms of viral infection, such as chlorotic mottling and leaf deformation. Samples were transported and stored at $4^{\circ} \mathrm{C}$ until testing by ELISA or stored at $-20^{\circ} \mathrm{C}$ until RNA extraction and RT-PCR.

\section{Serological detection}

Serological testing was performed utilizing doubleantibody sandwich (DAS)-ELISA kits with commercial antisera specific for detection of CMV and INSV (Loewe Biochemica, Germany), following the manufacturer's instructions. Plant tissue samples were ground in extraction buffer (1:10 wt/vol). After incubation with p-nitrophenyl phosphate (Sigma-Aldrich, St. Louis, MO) at room temperature for $2 \mathrm{~h}$ in the dark, absorbance at $405 \mathrm{~nm}$ was measured with an ELISA microplate reader (Multiskan Ascent, Finland). Commercial positive and negative controls and extracts from healthy pot marigold tissue were included in each test. Samples were considered as positive if the mean absorbance value at $405 \mathrm{~nm}$ was at least twice that of the negative control.

\section{Mechanical transmission}

Five plants of each Chenopodium quinoa, $C$. amaranticolor, Nicotiana tabacum 'Samsun', N. glutinosa, and Datura stramonium as well as Calendula officinalis seedlings were mechanically inoculated with sap from the leaves of five serologically positive samples, one sample from each locality, using $0.01 \mathrm{M}$ phosphate buffer ( $\mathrm{pH} 7$ ). The test plants were inoculated at the 2-3 true-leaf stage and maintained under greenhouse conditions for symptoms to develop over a period of up to four weeks post-inoculation. All inoculated plants were assayed by DAS-ELISA to confirm CMV presence.

\section{RT-PCR detection}

Presence of CMV in pot marigold plants was further confirmed by conventional reverse transcription (RT)-PCR. Total RNAs were extracted from $100 \mathrm{mg}$ leaf tissue by the
RNeasy Plant Mini Kit (Qiagen, Hilden, Germany) according to the manufacturer's instructions and used as template in RT-PCR. RT-PCR was carried out using the One-Step RT-PCR Kit (Qiagen) using CMV-specific primer pair, CMVCPfwd and CMVCPrev (Milojević et al. 2012), which amplifies an 871-bp fragment of the entire coat protein $(\mathrm{CP})$ gene.

The RT-PCR reaction mixture included $400 \mu \mathrm{M}$ each of the four dNTPs, $1 \mu \mathrm{l}$ of RT-PCR enzyme mix, $0.6 \mu \mathrm{M}$ each primer and $1 \mu \mathrm{l}$ extracted RNA in a final volume of 25 $\mu$ l. Amplifications were performed in a thermal cycler (Eppendorf, Germany) under the following programs: reverse transcription at $50^{\circ} \mathrm{C}$ for $30 \mathrm{~min}$ and an initial PCR denaturation step at $95^{\circ} \mathrm{C}$ for $15 \mathrm{~min}$, followed by 35 cycles consisting of a denaturation step of $30 \mathrm{~s}$ at $94^{\circ} \mathrm{C}$, primer annealing for $30 \mathrm{~s}$ at $58^{\circ} \mathrm{C}$, and extension for $30 \mathrm{~s}$ at $72^{\circ} \mathrm{C}$. The final extension was performed at $72^{\circ} \mathrm{C}$ for $10 \mathrm{~min}$. Total RNAs obtained from a Serbian CMV isolate from pepper (GenBank Accession No. KC288146) and a healthy pot marigold plant served as the positive and the negative control, respectively. The amplification fragments were determined using electrophoresis on $1 \%$ agarose gel containing ethidium bromide $(0.5 \mu \mathrm{g} / \mathrm{mL})$. The expected size of the amplified fragments was estimated by comparison with O'RangeRuler ${ }^{\mathrm{TM}} 100$ bp DNA Ladder, ready-to-use (Fermentas, Lithuania). The agarose gel was visualised in UV transilluminator, and the images were captured with DOC PRINT system (Vilbert Lourmat, USA).

\section{Sequencing and phylogenetic analysis}

Products of a predicted size, obtained in RT-PCR assays from isolates, 231Cal originating from Srbobran locality were sequenced directly after the purification with QIAquick PCR Purification Kit (Qiagen). Additionally, a previously identified pot marigold CMV isolate $232 \mathrm{Mrg}$ (Milošević et al. 2015) was also included in the investigation.

Sequence of the Serbian CMV isolate was compared with the previously reported CMV isolates available in the GenBank (http://www.ncbi.nlm.nih.gov/BLAST/) using the ClustalW program (Thompson et al. 1994) and MEGA5 software (Tamura et al. 2011). A p-distance model was applied for nucleotide (nt) and deduced amino acid (aa) sequence analyses.

A phylogenetic tree was constructed using $40 \mathrm{CP}$ sequences of CMV isolates retrieved from GenBank (Table 1) and those CMV CP sequences generated in this study and using the Maximum Parsimony (MP) method in MEGA5 software. The reliability of the obtained tree was evaluated using the bootstrap method based on 1000 replicates, and bootstrap values $<50 \%$ were omitted. An isolate of Peanut stunt virus (Acc. No. U15730) was used as the outgroup sequence (Table 1). Intra- and inter-group diversity values were calculated as the average genetic distance using Kimura 2-parameter model Gamma distributed $(\mathrm{K} 2+\mathrm{G})$ which was chosen as the best-fitting model of nt substitution. 
Table 1. CMV isolates with coat protein sequences used in the phylogenetic analysis

\begin{tabular}{|c|c|c|c|c|}
\hline Virus & Isolate $^{a}$ & Country & Host & Gen Bank Acc. No. \\
\hline $\mathrm{CMV}^{\mathrm{b}}$ & 231Cal & Serbia & Calendula officinalis & KP765696 \\
\hline CMV & $232 \mathrm{Mrg}$ & Serbia & Calendula officinalis & KP034963 \\
\hline CMV & MAD99/4 & Spain & Cucurbita pepo & AJ829770 \\
\hline CMV & MAD96/1 & Spain & Cucumis melo & AJ829768 \\
\hline CMV & $\mathrm{I} 17 \mathrm{~F}$ & France & / & X16386 \\
\hline CMV & MAD99/1 & Spain & Cucumis melo & AJ829776 \\
\hline CMV & Ban & Israel & Musa sp. & U43888 \\
\hline CMV & $702-07$ & Serbia & Nicotiana tabacum & GQ340670 \\
\hline CMV & CMV-P6 & USA & Nicotiana tabacum & D10545 \\
\hline $\mathrm{CMV}$ & 207 & Australia & Lycopersicon esculentum & AJ585517 \\
\hline CMV & $151-08$ & Serbia & Cucurbita pepo & HM065509 \\
\hline CMV & $115-08$ & Serbia & Cucurbita pepo & HM065510 \\
\hline CMV & CMV-FC & USA & Nicotiana tabacum & D10544 \\
\hline CMV & PR36 & USA & / & M98500 \\
\hline CMV & - & Colombia & Musa sp. & U32859 \\
\hline CMV & P1 & China & / & AJ006988 \\
\hline CMV & $\mathrm{KM}$ & Japan & Cucumis melo & AB004780 \\
\hline CMV & Cas & Poland & Lilium sp. & DQ018286 \\
\hline CMV & $\mathrm{RB}$ & China & Phaseolus vulgaris & AJ006990 \\
\hline CMV & 113 & USA & / & AF523340 \\
\hline CMV & NT9 & Taiwan & / & D28780 \\
\hline CMV & Trk7 & Hungary & Trifolium repens & L15336 \\
\hline CMV & $\mathrm{C} 7-2$ & Japan & / & D42079 \\
\hline CMV & M-48 & Taiwan & / & D49496 \\
\hline CMV & K & USA & / & AF127977 \\
\hline CMV & $\mathrm{ABI}$ & Korea & Gladiolus sp. & L36525 \\
\hline CMV & Tfn & Italy & Lycopersicon esculentum & Y16926 \\
\hline CMV & Ixora & USA & Ixora sp. & U20219 \\
\hline CMV & Oahu & Hawaii & Musa sp. & U31220 \\
\hline CMV & S & USA & Cucurbita pepo & AF063610 \\
\hline CMV & $\mathrm{Q}$ & Australia & Capsicum annumm & M21464 \\
\hline CMV & LS & USA & Lactuca sativa & AF127976 \\
\hline CMV & Simp2 & Poland & Lilium sp. & FJ621495 \\
\hline $\mathrm{CMV}$ & M2 & Japan & / & AB006813 \\
\hline CMV & Kin & United Kingdom & / & Z12818 \\
\hline CMV & Ri-8 & Spain & Lycopersicon esculentum & AM183119 \\
\hline CMV & Pl-1 & Spain & Lycopersicon esculentum & AM183116 \\
\hline CMV & $\mathrm{SD}$ & China & Nicotiana tabacum & AB008777 \\
\hline CMV & Tsh & China & Lycopersicon esculentum & EF202597 \\
\hline CMV & $\mathrm{TN}$ & Japan & Lycopersicon esculentum & AB176847 \\
\hline CMV & $\mathrm{Ns}$ & Hungary & Nicotiana glutinosa & AJ511990 \\
\hline CMV & Rs & Hungary & Raphanus sativus & AJ517802 \\
\hline PSVc & ER & India & Vigna unguiculata & U15730 \\
\hline
\end{tabular}

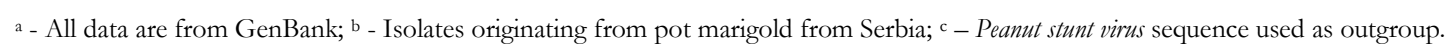




\section{Results and Discussion}

Virus detection and symptomatology in the field

During the visual inspection of pot marigold fields in 2014, similar symptoms were observed in all inspected localities with disease incidence ranging from 15 to $50 \%$. Mosaic was the most frequent symptoms, varying from mild to strong, as well as various chlorotic streaks, mild leaf deformation, and more or less pronounced blistering. The observed symptoms were typical of CMV infection, as described by many authors (Hanson et al. 1951, Sang \& Varma 1975, Naqvi et al. 1981, Rahaman \& Rao 1992).

Serological analysis of pot marigold samples, revealed the presence of CMV in all inspected localities in the Province of Vojvodina. The presence of CMV was detected serologically in $67.16 \%$ tested samples and all were negative for INSV (Table 2). After the first detection of CMV in 7 out of 10 tested pot marigold samples originating from the Đurđevo locality, the virus was detected serologically in additional 38 pot marigold samples collected from four different localities: Srbobran, Ruma, Zrenjanin, and Žitište. The highest incidence of CMV was in the Đurđevo locality (70\% tested samples positive), as well as in the Srbobran locality, where the presence of the virus was confirmed in 7 out of 15 tested samples $(46.66 \%)$. In the locality of Zrenjanin the presence of CMV was detected in $35.71 \%$ tested samples, while in Ruma locality presence of the virus was confirmed in $23.08 \%$ tested samples. In Žitište locality the presence of the virus was detected only in 3 out of 15 pot marigold samples.

The natural occurrence of CMV in pot marigold was reported by Hanson et al. (1951), Joshi \& Dubey (1972) and Sang \& Varma (1975). As a new CMV host in Serbia, pot marigold represents a potential virus reservoir and additional source of inoculum to recognize the known host range and prevalence of CMV in weed hosts.

\section{Mechanical transmission}

All five selected samples of naturally infected pot marigold plants, one from each locality, that were serologically positive for CMV, were successfully transmitted mechanically to the test plants. All inoculated plants produced the symptoms, which is in correlation with earlier descriptions (Singh et al. 1999, Iqbal et al. 2011) from 5 to 10 days post-inoculation. All five mechanically inoculated Chenopodium amaranticolor and $C$. quinoa reacted uniformly showing small local lesions, while systemic mosaic and leaf malformations were observed on Nicotiana tabacum 'Samsun' and N. glutinosa, 5-6 and 10 days postinoculation, respectively. Also, the virus was successfully mechanically transmitted to $C$. officinalis that reacted with symptoms identical to those observed on the original host plants. Serbian CMV isolate from pot marigold were not able to infect $D$. stramonium plants, though this plant is reported as experimental host plant of CMV (Iqbal et al. 2011). Test plants were assayed by DAS-ELISA and all inoculated plants of each species tested positive for CMV.

\section{Molecular detection, identification and phylogenetic analysis}

The results of serological analyses of CMV presence in pot marigold crops in Serbia was further confirmed by molecular RT-PCR method using specific primers CMVCPfwd and CPrev which amplify fragment covering the entire coat protein (CP) gene and part of 3'- and 5'-UTRs. These primers successfully detected the presence of CMV in all tested samples and amplified cDNA fragments of predicted size. One clear band of 871 bp was visible in all tested samples as well as in positive control. No amplicon was recorded when extract from the healthy pot marigold plant was used as template in the RT-PCR assay.

Table 2. Presence and incidence of Cucumber mosaic virus in pot marigold during 2014

\begin{tabular}{lccc}
\hline Locality & District & Tested samples & Positive samples \\
\hline Đurđevo & South Bačka & 10 & $7(70 \%)^{\mathrm{a}}$ \\
Srbobran & South Bačka & 15 & $7(46.66 \%)$ \\
Ruma & Srem & 13 & $3(23.08 \%)$ \\
Zrenjanin & Central Banat & 14 & $5(35.71 \%)$ \\
Žitište & Central Banat & 15 & $3(20 \%)$ \\
\hline Total & & 67 & $25(37.31 \%)$ \\
\hline
\end{tabular}

a - Number of infected samples (\% infected samples calculated over the total number of tested samples). 
After purification, the RT-PCR product derived from the isolate $231 \mathrm{Cal}$ was directly sequenced in both directions using the same primer pair as in RT-PCR and deposited in GenBank (GenBank Accession No. KP765696). Sequence analysis of CP gene, conducted with MEGA5 software, revealed 99.5\% nt identity $(100 \%$ aa identity) between the two Serbian CMV isolates from pot marigold. Multiple sequence alignment of the CP open reading frame showed that the Serbian isolate 231Cal shared the highest nucleotide identity of 99.5\% (100\% amino acid identity) with six CMV isolates from Poland (EU191027, DQ018292), Italy (FN257306), Iran (KC763473), China (EF202597), and Serbia (KC414925).

A Maximum parsimony tree (Figure 1) reconstructed using the partial sequences of the coat protein gene revealed that $\mathrm{CMV}$ isolates determined in this study and selected sequences of 40 previously characterized CMV isolates retrieved from GenBank database clustered into two groups supported with high bootstrap values (100\%). Group I was further divided into two subgroups IA and IB. The division of isolates into three subgroups (IA, IB and II) is in accordance with the previous reports (Palukaitis \& Zaitlin 1997, Roossinck et al. 1999). Genetic diversity among two molecular groups of isolates was $0.151 \pm 0.083$, whereas within each group and subgroups were: $0.010 \pm 0.004$ (IA), $0.036 \pm 0.015$ (IB) and $0.012 \pm 0.005$ (II). Subgroup IA contained 19 isolates from different parts of the world, Europe (Spain, Hungary, Serbia, Poland and France), Asia (Japan, China and Israel), America (USA and Colombia) and Australia. Subgroup IB contained 12 isolates from Europe (Spain and Italy), Asia (Japan, China, Taiwan and Korea), and America (USA and Hawaii). In subgroup II nine isolates classified from Europe (Hungary and Poland), Asia (Japan and China), Africa (South Africa), North America (USA), UK, Australia as well as two Serbian CMV isolates from pot marigold.

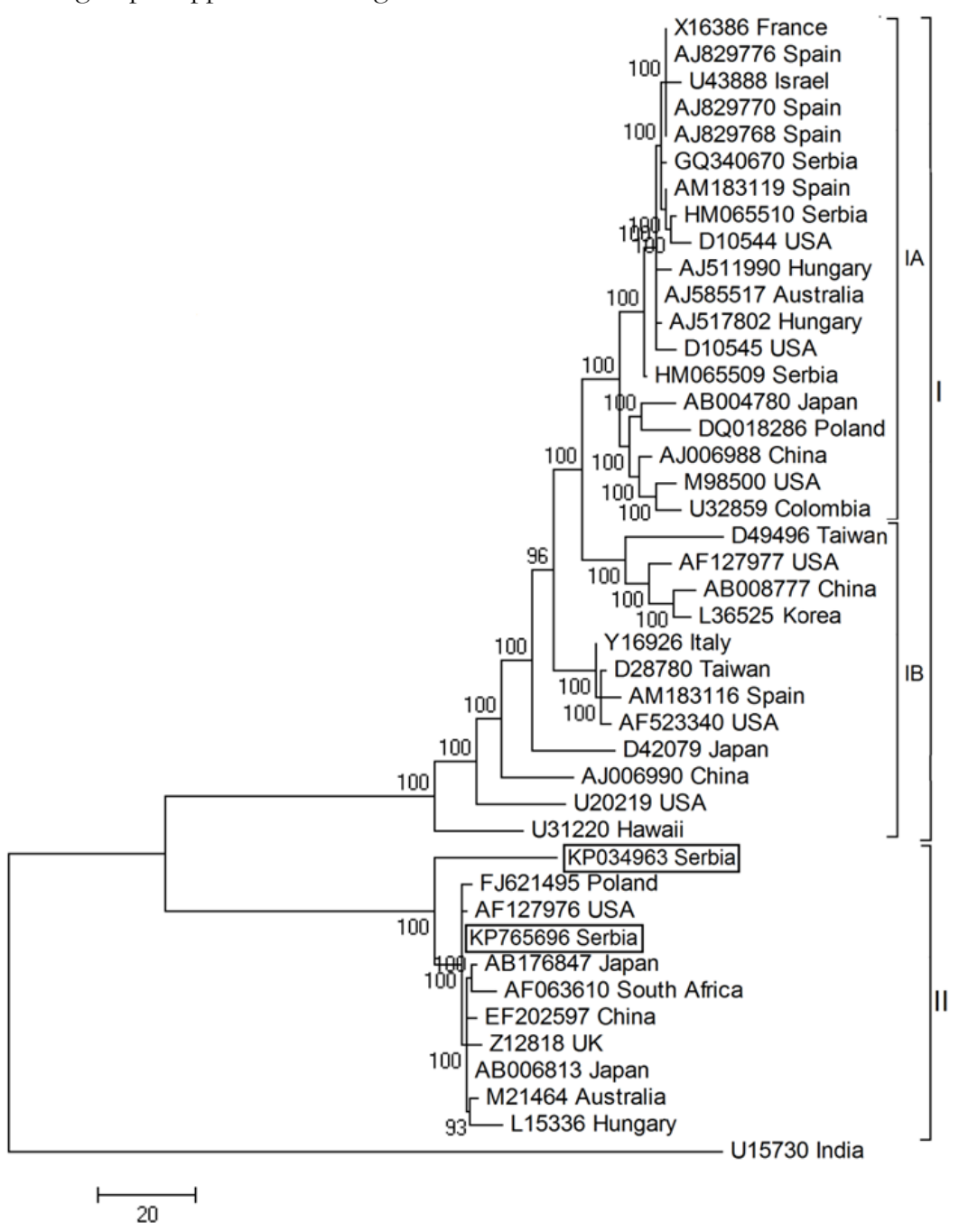

Figure 1. Maximum parsimony tree of was constructed based on nucleotide sequences of partial CP sequence of $42 \mathrm{CMV}$ isolates. Phylogram was generated with MEGA5 using bootstrap analysis with 1000 replicates and bootstrap values $(>50 \%)$ are shown next to relevant branches. The tree was rooted with Peanut stunt virus (U15730). The two Serbian isolates from pot marigold are framed. 
Considering that pot marigold has been traditionally grown in Serbia, as one of the most significant medicinal plants, the occurrence of CMV can represent a limiting factor for its successful production. As CMV can often be found on various crops in Serbia (Krstić et al. 2002, Dukić et al. 2004, Vučurović et al. 2009, Milojević et al. 2013), then due to its easy transmitting in a non-persistent manner by aphids, and a wide circle of hosts (Garcia-Arenal \& Palukaitis 2008), constant monitoring of CMV status and presence in our country is necessary.

\section{Conclusions}

After previously reported outbreak of CMV on pot marigold as a new host in Serbia for the first time, in this study the virus was detected in four additional localities in the Province of Vojvodina using DASELISA tests, bio assay, and molecular detection by RTPCR with specific primers. Sequencing of CP gene of selected isolates from pot marigold and suitable phylogenetic analysis showed the position of Serbian CMV isolate from pot marigold in CMV population worldwide. Due to great damages caused by CMV worldwide, determination of variability within population of CMV in pot marigold crops, but also establishing relationships with the isolates originating from other hosts in Serbia will contribute to the clarification of some unknown epidemiological aspects and discovery of plants significant for viral conservation, with the general purpose to design and implement efficient control and prevent the possible introduction of new viral strains in our country through intensive international exchange of plant material.

\section{References}

Blumenthal, M. (2000). Herbal Medicine. Expanded Commission and Monographs, Integrative Medicine Communication, New York.

Dukić, N., Berenji, J., Krstić, B., Vico, I. \& Bulajić, A. (2004). Prisustvo i rasprostranjenost viroza obične tikve (Cucurbita pepo L.) u Vojvodini. Bilten za hmelj, sirak i lekovito bilje, 35/36, 71-79.

Edwardson J.R. \& Christie R.G. (1997). Viruses infecting peppers and other Solanaceous crops. Gainesville. University of Florida Press.

Francki, R.I.B., Mossop, D.W. \& Hatta, T. (1979). Cucumber mosaic virus. CMI/AAB Description of Plant Viruses, No 213.

Garcìa-Arenal, F. \& Palukaitis, P. (2008). Cucumber mosaic virus. In Mahy, B. W. J. and van Regenmortel, M.H.V. (eds.) Desk Encyclopedia of Plant and Fungal Virology. Elsevier, Amsterdam, 171-176.

Ghotbi, T. (2013). Serological and Molecular detection of INSV and introduction of some INSV ornamental host plants from five provinces in Iran. Iranian Journal of the plant pathology, 49910, 131.

Hamburger, M., Adler, S., Baumann, D., Forg, A. \&Weinreich, B. (2003). Preparative purification of the major anti-inflammatory triterpenoid esters from marigold (Calendula officinalis). Fitoterapid 74, 328-338.

Hanson, H.R., Weber, H.R. \& Troelsen Johansan, G. (1951). Plant disease in Denmark in 1949. Annual survey of data collected by the state phytopathological service, Lyngby. T. Planteavl., 55, 181.
Iqbal, S., Ashfaq, M. \& Shah, H. (2011). Biological characterization of Pakistani isolates of Cucumber mosaic cucumovirus (CMV). Pakistan Journal of Botany, 43: 3041-3047.

Joshi, R.D. \& Dubey, L.N. (1972). Studies on a mosaic disease of marigold (Tagetes erecta L.). U. P. Science and Cult. 38, 147-148.

Kalvatchev, Z., Walder, R. \& Garzaro, D. (1997). Anti-HIV activity of extracts from Calendula officinalis flowers. Biomedicine ¿Pharmacotherapy, 51, 176-180.

Krstić, B., Berenii, J., Dukić, N., Vico, I., Katis, N.I. \& Papavassiliou, C. (2002). Identification of viruses infecting pumpkins (Cucurbita pepo L.) in Serbia. Zbornike Matice srpske za prirodne nauke, 103, 57-65.

Milojević, K., Stanković, I., Vučurović, A., Ristić, D., Nikolić, D., Bulajić, A. \& Krstić, B. (2012). First report of Cucumber mosaic virus infecting watermelon in Serbia. Plant Disease, 96, 1706.

Milojević, K., Stanković, I., Vučurović, A., Ristić, D., Nikolić, D., Bulajić, A. \& Krstić B. (2013). Biološka i molekularna karakterizacija virusa mozaika krastavca poreklom iz lubenice u Srbiji. Zaštita bilja, 64 (1), 283, 14-25.

Milošević, D., Ignjatov, M., Nikolić, Z., Gvozdanović-Varga, J., Petrović, G., Stanković, I. \& Krstić, B. (2015). First Report of Cucumber mosaic virus causing chlorotic mottle on Pot Marigold (Calendula officinalis) in Serbia. Plant Disease. http:// dx.doi.org/10.1094/PDIS-11-14-1208-PDN

Naqvi, Q.A., Hadi, S. \& Mahmood, K. (1981). Marigold mottle virus in Aligarh, India. Plant Disease, 65, 271-275.

Palukaitis, P. \& Zaitlin, M. (1997). Replicasemediated resistance to plant virus diseases. Advances in Virus Research, 48, 349-377.

Petrović, D., Bulajić, A., Stanković, I., Ignjatov, M., Vujaković, M. \& Krstić, B. (2010). Prisustvo i rasprostranjenost virusa paprike u Srbiji. Ratar. Pourt., 47(2), 567-576.

Ramos, A., Edreira, A., Vizoso, A., Betancourt, J., Lopez, M. \& Decalo, M. (1998). Genotoxicity of an extract of Calendula officinalis. Journal of Ethnopharmacology. 61, 49-55.

Rahaman, M.A. \& Rao, N.G. (1992). A mosaic disease of marigold caused by a potyvirus. Indian Journal of Plant Protection, 20(2), 239 -240 .

Roossinck, M.J., Zhang, L. \& Hellwald, K. (1999). Rearrangements in the $5^{\prime}$ nontranslated region and phylogenetic analyses of cucumber mosaic virus RNA 3 indicate radial evolution of three subgroups. Journal of Virology, 73, 6752-6758.

Sang, A. \& Varma A. (1975). Marigold mosaic virus. Phytopathol. Z. $84: 10-17$

Singh, D., Naqvi, Q.A. \& Garg, J.D. (1999).A strain of cucumber mosaic cucumovirus causing mosaic in marigold in India. Indian Phytopathology, 52 (2), 114-117.

Stanković, I., Bulajić, A., Vučurović, A., Ristić, D., Milojević, K., Berenji, J. \& Krstić B. (2011). Status of tobacco viruses in Serbia and molecular characterization of Tomato spotted wilt virus isolates. Acta Virologica, 55 (4), 337-347.

Tamura, K., Peterson, D., Peterson, N., Stecher, G., Nei, M. \& Kumar, S. (2011). MEGA5: Molecular evolutionary genetics analysis using maximum likelihood, evolutionary distance, and maximum parsimony methods. Molecular Biology and Evolution, $28,2731-2739$.

Thompson, J.D., Higgins, D.G. \& Gibson, T.J. (1994). CLUSTAL W: Improving the sensitivity of progressive multiple sequence alignment through sequence weighting, position specific gap penalties and weight matrix choice. Nucleic Acids Research, 22, 4673-4680.

Vučurović, A., Bulajić, A., Đekić, I., Ristić, D., Berenji, J. \& Krstić, B. (2009). Prisustvo i rasprostranjenost virusa uljane tikve molekularna karakterizacija virusa žutog mozaika cukinija. Pesticidi i fitomedicina, 24, 85-94.

Vučurović, A., Bulajić, A., Stanković, I., Ristić, D. \& Krstić, B. (2011). Karakterizacija virusa mozaika krastavca poreklom iz tikava u Srbiji. Pesticidi i fitomedicina, 26, 325-336.

Vučurović, A., Bulajić, A., Stanković, I., Ristić, D., Berenji, J., Jović, J. \& Krstić, B. (2012). Non-persistently aphid-borne viruses infecting pumpkin and squash in Serbia and partial characterization of Zucchini yellow mosaic virus isolates. European Journal of Plant Pathology, 133, 935-947. 


\section{Prisustvo virusa mozaika krastavca na nevenu (Calendula officinalis L.) u Srbiji}

\section{Dragana Milošević • Maja Ignjatov • Zorica Nikolić · Jelica Gvozdanović Varga • Gordana Tamindžić · Ivana Stanković · Branka Krstić}

Sažetak: Tokom 2014. godine, sa pet različitih lokaliteta gajenja nevena u Vojvodini sakupljeno je ukupno 67 uzorka koji su serološki testirani na prisustvo virusa mozaika krastavca (Cucumber mosaic virus, CMV) i virusa nekrotične pegavosti impatiensa (Impatiens necrotic spot virus, INSV), korišćenjem komercijalno dostupnih kitova za DAS-ELISA test. Prisustvo CMV dokazano je na svih pet pregledanih lokaliteta i to u $67,16 \%$ prikupljenih uzoraka, dok prisustvo INSV nije dokazano ni u jednom od testiranih uzoraka. Virus je uspešno prenet mehaničkim inokulacijama test biljaka Chenopodium amaranticolor, C. quinoa, Nicotiana tabacum 'Samsun' i N. glutinosa, kao i na sejance nevena, čime je potvrđena infektivna priroda oboljenja. Prisustvo CMV u biljkama nevena potvrđeno je primenom RT-PCR metode i sekvencioniranjem uz korišćenje specifičnih prajmera CMVCPfwd/ CMVCPrev koji omogućavaju umnožavanje gena za protein omotača (CP gena). Filogenetska analiza na osnovu sekvence CP gena pokazala je grupisanje izolata u tri podgrupe, IA, IB i II, a izolati CMV iz nevena iz Srbije grupišu se u podgrupu II.

Ključne reči: Calendula, gen za protein omotača, izolati, neven, RT-PCR, sekvencioniranje, virus mozaika krastavca, virus nekrotične pegavosti impatiensa 